\title{
Biomedical institute suffers growing pains
}

Erika Check, Washington

With a new director on the way and its first major round of grants set to be awarded later this year, the US National Institute of Biomedical Imaging and Bioengineering (NIBIB) is ready to roll.

But this latest member of the National Institutes of Health (NIH) is already ruffling its siblings' feathers, as researchers watch existing programmes move to the new body - and wonder if their project will be next.

The NIBIB caused unease even before it came into existence in 2000. Many NIH staff, including former director Harold Varmus, opposed it, saying that it would disrupt existing research and increase NIH bureaucracy.

And the arrival this May of the NIH's new director, Elias Zerhouni, a radiologist by training who backed the NIBIB's creation before he was appointed, caused speculation that it could be favoured above other institutes. "There is a lot of anxiety about the new institute among NIH staff and NIH-funded researchers," says one senior NIH official.

Few NIH researchers are willing to criticize the NIBIB in public, but many are voicing their fears in private. Doubts centre on the group of experts charged by Congress with setting the institute's budget and research agenda. Six of the nine-member group were representatives of two bodies that backed the NIBIB's creation - the Academy of

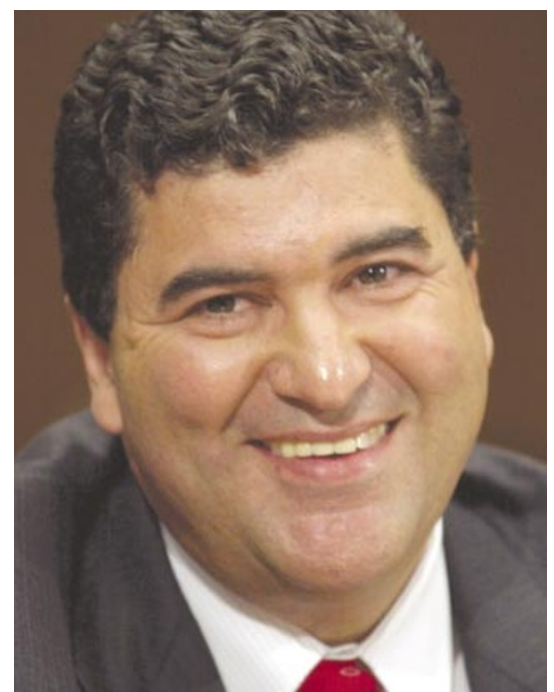

Elias Zerhouni says tensions over the biomedical imaging and bioengineering institute will ease.

Radiology Research and the American Institute for Medical and Biological Engineering. The remaining three were NIH staff.

Of the \$112-million budget set for the NIBIB this year, $\$ 67$ million came from funds transferred from other institutes. But the group has recommended that a further $\$ 150$ million be transferred in the next financialyear. "The money has to come from some- where, and nobody wants to see a reduction in their area," says another NIH official.

The process by which grants are chosen for transfer is also raising hackles. The first round was picked by NIH officials, but the second list was drawn up earlier this year by the working group. Some NIH staff say many programmes that are disease-specific should have stayed in other institutes.

"A lot of the transfers didn't make sense," agrees Mike Marron, director of the Division of Biomedical Technology at the NIH's National Center for Research Resources. "The process certainly was not transparent."

Donna Dean, acting director of the institute, says that the new body is focusing on previously undersupported areas. Sensors to detect weapons of mass destruction have, for example, become a hot topic since 11 September. "Sensors seemed to be an area that no one was taking strong ownership of," she says. "We thought this is an area we can take on."

In the long run, the NIBIB's fate is in the hands of new director Roderic Pettigrew, a medical-imaging expert from the Emory University School of Medicine in Atlanta, Georgia, who arrives in September. And Zerhouni is confident that the institute will work through its growing pains. "This sense of tension is a natural epiphenomenon of the creation of any new initiative," he says. "I don't see that it will have lasting effects.”

\section{Opponents of stem-cell patent win restrictions}

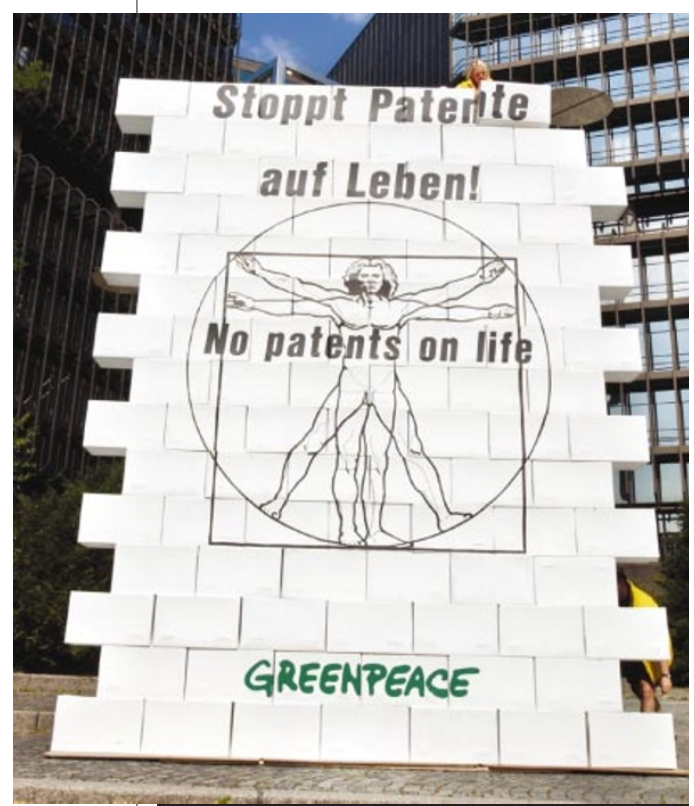

Live issue: since it was granted in 1999, the 'Edinburgh patent' has faced stiff opposition.
Alison Abbott and Oliver Schmidt, Munich A controversial patent covering technologies for purifying human and animal stem cells has been restricted in scope by the European Patent Office (EPO).

In a ruling issued on 24 July, the EPO's oppositions division narrowed the patent held by the University of Edinburgh's Centre for Genome Research, invalidating all claims involving animal and human embryonic stem cells.

The patent, which details techniques for isolating and propagating genetically engineered adult or embryonic stem cells, generated widespread complaints when it was granted in December 1999.

Starting in March 2000, 14 parties, including Greenpeace and the German, Italian and Dutch governments, filed objections. Most opposed the patent because it involved techniques for working with human embryonic cells (see Nature 404, 3-4; 2000). The DFG, Germany's main research funding agency, objected on technical grounds, claiming that the University of Edinburgh had not revealed enough technical information about the methods involved.

Shortly after the objections were filed, the university withdrew parts of the patent that covered technologies that could be used to alter the composition of the human germ line. But the EPO's ruling on the formal objections has gone further, leaving only claims covering adult stem cells intact.

The patent office says that its decision was partly based on ethical grounds uses of human embryos are excluded from patentability according to EPO rules - and partly due to the patent's failure to disclose sufficient information for the techniques to be repeated by stem-cell experts.

Oliver Brüstle, a stem-cell researcher at the University of Bonn, fears that the ruling will send a negative signal to researchers. "It could mean that it will be difficult for researchers to get protection for intellectual property on human embryonic stem cells in the future," he says.

But Bernard Huber, a lawyer for the DFG, points out that the EPO's decision applies only to this particular case, and so cannot be generalized. 